\title{
A Survey of Iranian EFL Teachers' and Learners' Perceptions Toward Authentic Listening Materials at University Level
}

\author{
Amir Mahdavi Zhafarghandi \\ University of Guilan, Iran \\ E-mail: mahdavi1339@gmail.com \\ Behzad Barekat \\ Faculty member at the University of Guilan, Iran \\ E-mail: behzadbarekat@yahoo.com \\ Sepideh Homaei (Corresponding author) \\ MA student at TEFL at the University of Guilan, Iran \\ E-mail: sepideh.homaei64@gmail.com
}

Doi:10.7575/aiac.alls.v.5n.4p.184

Received: 18/06/2014

URL: http://dx.doi.org/10.7575/aiac.alls.v.5n.4p.184

Accepted: 04/08/2014

\begin{abstract}
This study intends to deal with attitudes of teachers and learners toward authentic listening materials at preintermediate level. Studies have indicated the positive effect of authentic listening materials on motivation and listening comprehension ability in learners of English as a foreign language (Nuttall, 1996; Peacock, 1997; Miller, 2005; Field, 2008). It focused on EFL teachers and students at pre intermediate proficiency level. Participants included 60 students, from both gender; male and female university students studying at Rodaki Higher Institute Education in the fields of: Accounting, Computer Engineering and Commercial Management and also 30 teachers who taught listening at Rodaki Higher Institute Education. The students were randomly selected and assigned to two groups. Then, Oxford Placement test as a standard test was administered to the participant in order to determine their proficiency level. Then, the participants were divided into two groups of control and experiment. The experiment group received the listening materials taken from UK radio program whereas the other group received simplified listening materials taken from the authentic listening materials. Afterwards, to be sure that they know what authentic materials are, they were exposed to both of related materials, then the questionnaire was distributed among them, the results taken from the questionnaire showed that the participants of this study prefer authentic materials and have positive attitudes toward using them. By the same token, the analysis of teachers' questionnaire also showed their satisfaction with authentic listening materials. These findings can have implications for language learning/teaching, and curriculum development paving the way for educational policy makers, teachers and learners to introduce authentic listening materials to EFL learners at preintermediate proficiency level.
\end{abstract}

Keywords: English as a Foreign Language (EFL), listening skill, authentic materials, pre-intermediate

\section{Introduction}

One of the most important skills of learning a foreign language that has been mostly ignored in EFL situation is listening (Nunan, 2000). In classic methods of teaching English as second or foreign language, listening was defined as a passive, receptive skill (Schmitt, 2002). However, over the time the classical view of listening ability has changed and now it is regarded as an active and productive process (Schmitt, 2002). The new millennium has witnessed the special attention given to this domain in applied linguistics and related disciplines. Emersion of communicative approach to language teaching caused a lot of efforts by scholars of language teaching and educational policy makers to use the reallife materials for teaching language skills. However, presenting real-life and authentic materials in language classes and curriculum was faced with controversies and antithetical views. Some scholars encourage the application of authentic materials in foreign language classrooms while others are strongly cautious. Authenticity has been defined differently in literature. McNeil (1994) mentions that scholars and educational experts have been arguing pros and cons of using authentic materials. By reviewing the related literature it becomes clear that using authentic materials has been mentioned a lot. It directly and effectively affects and is affected by other skills especially, speaking. In other words, our speaking shapes and is shaped by listening, how we are involved in listening, what we listen to, how we listen and how we are grown up with it. McNeil (1994) and Kilickaya (2004) stated that now using authentic texts is considered as a way for motivating students to learn. It is due to the fact that authentic texts make the learner feel being in a real situation and learning the target language as it is communicated by the native speakers. Empirical studies (Bacon \&Finnemann's, 1990; Otte, 2006; Thanajaro, 2000) have proven that exposure to aural authentic texts has increased the motivation and self-satisfaction of the language learners. However, Guariento and Moreley (2001) have claimed that 
difficulty of understanding real-life aural texts could be removed by defining partial comprehension as the target of listening tasks. Furthermore the advantages of authentic materials for foreign language learning overweigh the problems and troubles. Moreover, entailing authentic materials in the classroom would be beneficial for FL learners and teachers in terms of time and effort. The issue of when to introduce authentic materials has face controversies in the field of language teaching. On the other hand, some researchers including Kilickaya (2004) and Kim (2000) stated that authentic materials are only applicable for language learners at intermediate and advanced levels. According to them, using authentic materials at lower levels is not supported since language learners of lower than intermediate level lack enough lexical and structural understandings of the target language and so, they would be demotivated and frustrated by receiving authentic materials. "At lower levels, however, even with quite simple tasks...the use of authentic texts may not only prevent the learners from responding in meaningful ways but can also lead them to feel frustrated, confused, and, more importantly, demotivated" (p.347). Kim (2000) discussed that authentic language do not provide a comprehensible input for the learners at lower level of language acquisition. However, other scholars and researchers claim that authentic materials should be provided at primary levels of learning language since exposure to authentic materials helps them develop strategies for learning more complicated tasks at later stages (McNeil, 1994; Miller, 2005)

\subsection{Statement of the problem}

It is thought that non-native speaking teacher' and non-native learners' views would be valuable as they themselves are often successful learners and would know better of its benefits if any. Miller (2003) indicates that a survey conducted on The ESL Magazine website concerning the most used medium for obtaining authentic listening materials for ESL/EFL instruction found the TV the most used one). ). The literature indicates that researchers have studied the effect of real-life materials on learners' comprehension and performance at different levels of language learning. It is demonstrated that most of adult language learners spend most of their time on communicating through listening (Gilman \& Moody, 1984; Cited in Vandergrift, 1999). However, other scholars such as Nunan (1999) and Schmitt (2002) little pedagogical and educational studies are devoted to listening comprehension and its important role in language learning. Khalili \& Mahsefat (2012) indicate that listening comprehension is different from other language skills due to special features of redundancy, being transient and non-written. Listening has a crucial and undeniable role in every day communication and educational level. However, a little attention is given to develop listening ability in language construction and so EFL learners are deprived of the bereft of receiving a balanced level of listening. Then EFL policy makers have to use authentic listening materials in the classrooms to prepare language learners for real-life encounter and communication. Learning English in Iran is a matter of learning English as a foreign language in a situation where they do not need to communicate with each other in daily life. Some studies provided insights about learners' attitudes toward authentic input. In addition, pedagogical research sought to provide recommendations for material selection and sources. However, there is no study on teachers", and learners perception about using real-life materials in the language classes. Due to the important role the teachers can play in introducing authentic learning material in the classroom, the present study attempts to address this issue. As Navarro (2014) stated, a cursory glance at the studies done before shows that there is gap in EFL researches about language teachers and learners attitude on using authentic listening materials and its contributions on learning.

\subsection{Significance of the study}

According to Thanajaro and Shrum (2000) listening skills plays an important role in everyday verbal interactions and teaching process. Krashen's input hypothesis (1987) considers a significant role for listening in natural development of language acquisition. Krashen believes that exposure to natural listening materials is a prerequisite for development of language ability. Undoubtedly, this is one of the most rigorous claims which ascribe great importance to listening functions. The experience of developing listening ability is different for language learns; some may naturally develop it without difficulty while others may experience a great challenge and frustrating experience. Based on Peterson (2010) stated that listening was considered as a passive/ receptive language skill for a while. Then, scholars and researchers recognized the significant role of listening in language learning (Krashen, 1982) and new methods of teaching listening more comprehensibly were relieved. Listening skill found a key position in communicative-based methodologies (Feyten 1991; Hadley, 2001).There are some issues in the literature regarding the teachers' and learners' attitude toward authentic and pertinent materials to be reviewed. As a matter of easiness, we discuss them separately. Authenticity brings back the enquiry of what is accurate, real and integral about language (Breen1985) as far as the learners considerably depend on textbooks that are frequently used in Iran, and this may influence the language they produce, so the issues of authentic or inauthentic materials are posed. . In addition, Kim (2000) stated that certain cultural barriers of language learning could be overcome through applying authentic materials in language classrooms. Moreover, other researchers have ignored the key role and value of the authentic materials. For example, Clark (1983) argued that using media as authentic material in language learning classroom has no effect on students' learning; so, there is no difference between using authentic or non-authentic materials. Kilickaya (2004) further points out that real-life material include random contents and it is hard for teachers to organize the authentic materials to be presented in the classroom, pay the purchase cost, and spend a long time to prepare the authentic materials based on an acceptable pedagogical design. Such issues make the instructors unable to use real-life materials in the teaching plan. Schmidt (1994) states that authentic discourse may make the learners scared about facing the speed of delivery coupled with a combination of known and unknown structure and semantics. In teaching methodology, by advent of communicative approaches in teaching, educational policy makers tend to provide a real-life task (materials) as far as possible. Even after the advent of post method, exposing learners to language is a tenet. Developing learners' autonomy, facilitating and internalizing motivation are all principles in post method which can be exerted by authentic materials. As a post method tenet, "an 
urgency\& restructuring of classroom content and procedure"(Kumuravadevelue2001,p.538) serves as a notable way for building autonomy, providing many enriched, ubiquitous and easily-accessible sources for extensive learning, learning to learn, and raising cultural consciousness. Regarding teachers' perception, the literature is laden with various forms of teachers' and learners' opinions about different tips in applied linguistics in general. As McDonough (in Johnson and Johnson1998:14) says, attitude can be "opinions and belief, ways of responding with respect to some set of problems." Further attitude as it was suggested by Littlewood (1981) can be used for the investigation of subjects in need analyses. Overall exploring teachers' and learners' attitude toward authentic materials will be worthwhile.

\subsection{Review of literature}

There are slightly different definitions of authentic materials suggested in the related literature. Rogers (1988) stated the authentic materials as appropriate and qualified in terms of objectives, learners' needs and nature of the meaningful communication (p. 467). Hammer (2004) has stated authentic material as the ones designed for native speakers not for language students but for speakers of language. Jordan (1997) stated authentic texts as the ones which are not written for language teaching purposes. Peacock (1997) refers to authentic materials as the materials which are produced to meet purposeful social needs. Martinez (1983) stated that authenticity is a term which creates confusion because of a basic ambiguity. Therefore, the term authentic materials have been defined and used in different ways in the literature. The most common aspects of the definitions are exposure to real language and its use in natural way. Nunan (1989) defines authentic materials as any material which has not been specifically produced for the purposes of language teaching but is created to fulfill some social purpose in the language community in which it was produced". Rogers \& Medley (1988) used the term 'authentic' to refer to language samples that indicate natural form and an appropriateness of cultural and situational context that would be found in the language as used by the native speakers. Other definitions have focused on communicative nature of authentic materials. Lee (1995) said that is text is usually for a real life communicative purpose, where the writer has a certain massage to pass on to the reader. In other words, some researchers believe that definitions of authentic texts include more elements (Breen, 1985; Chaves, 1998; Jacobson, Degener, \& Purcell-Gates, 2003; Rings, 1986; Ur, 1996). Widdowson (1990), for example, differentiates authentic text and authentic discourse and says that " the language presented to [SL learners] may be genuine record of native speaker behavior, genuine, that is to say, as textual data, but to the extent that it does not engage native speaker response it cannot be realized as authentic discourse" (p.45). Breen (1985) in the same way stated that authenticity is not related to the language chose for teaching but to the tasks in which learners are engaged and the social condition of the classroom. He added that "authenticity to the target language needs to be seen as only one of a number of demands for authenticity which confront the teacher. The learners' own contributions, the activity of language learning, and the actual classroom situation are also constituent elements" (p.61).

\subsubsection{The role of authentic materials in FL teaching and learning}

There is growing body of research on the impact of authentic materials on FL teaching. Researchers and teachers have increasingly acknowledged the need for and usefulness of authentic materials in the field of language teaching. Empirical studies have substantiated the positive results taken by learners who have opportunities to interact with and deal with authentic texts. Studies, such as Miller (2005) and Thanajaro (2000), have shown the use of authentic materials lead in aural language development. In addition, Otte (2006) studied the impact of aural authentic texts on listening comprehension abilities of adult ESL students of an American university. He found that exposure to authentic materials would lead to better listening comprehension abilities and motivation of the language learners. By the same way, the study of Herron \& Seay (1991) on intermediate-level students indicated that the students who listened to authentic radio tapes as regular classroom activities had shown significantly greater listening comprehension than others. In addition, Berardo (2006) stated that several studies have confirmed that authentic materials can increase reading development by exposing students to new vocabulary and expressions. For example, Young (1999) have studied the reading comprehension of second year Spanish language students at a state university. It was revealed that authentic materials, as opposed to simplified, tended to better recall different versions of the same texts. In the same way, Leow (1993) studied the learners' absorption of chose linguistic items from both authentic and not authentic texts and he found that although understanding the non-authentic and simplified texts is easier but authentic texts would facilitate greater levels of absorption. Furthermore, Crossley and others (2007) studied the differences between sampled and simplified authentic reading texts by applying computational instruments. They understood that simplified texts have more complexity than the authentic texts for mature students. In this regard, Varney and Franciuli (1992) found that using authentic texts has clear advantages compared to the simplified texts in reading comprehension. Moreover, many experts of language teaching and pedagogy stated that applying authentic materials would improve the communicative ability of the learners (Guariento and Morely, 2001). Gilmore (2007) studied the effect of using authentic materials compared to textbook materials on developing the communicative competence of the learners during one year experiment. He concluded that the students who received the authentic input had significant improvements on different types of competence. He stated that "this result was attributed to the fact that the authentic input allowed learners to focus on a wider range of features than is normally possible ... and that this noticing had beneficial effects on learners' development of communicative competence". This way, Weyers (1999) studied the effect of exposure to real-life video materials on language acquisition of the university students, especially on listening skills and communicative competence. According to Ur (1996), understanding texts outside the classroom is troublesome for students since the reading materials used in the classroom do not illustrate the language in the real world. She argues that "we want our learners to be able to cope with the same kinds of reading that are encountered by native speakers of the target language" (p.150). Bantmeir (2008) stated that real life reading comprehension materials should be used as an 
inevitable part of language curriculum. Furthermore, Hadley (2001) found that "use of real or simulated travel documents, hotel registration forms, biographical data sheets, train and plane schedules, authentic restaurant menus, labels, signs, newspapers, and magazines will acquaint students more directly with real language than will any set of contrived classroom materials used alone" (p. 97).So, it seems that reading practices by use of different authentic materials is sensible for the students. It is also found that students at all levels have the ability to manage the authentic texts. Maxim (2002) found that "The students' limited linguistic competence did not short- circuit their ability to read authentic texts in class with the support of their classmates and instructor" (p.29). However, including authentic materials in foreign language classes has other advantages. Professors and experts of teaching language should maintain the enhancing power of the authentic materials (Gilmore, 2007).Findings of these studies have shown that using authentic materials is helpful in many ways. These types of materials students know how to use language in real world and improve their proficiency level in four skills of language learning. By the way, these good points show the opposite the arguments based on the fact that authentic materials prevent language learning. Gilmore (2007) also claimed that "authentic materials are a motivating force for learners are widespread through the literature" (p.106). McNeil and Kilickaya (2004) found that authentic texts make the language learners to feel learning authentic and real life language. The target language is used in a social context and its used is motivating for learning. Rivers (1987) confirms that students working with authentic materials have more interests in language learning. Kim (2000) stated that authentic materials provide a means for overcoming the cultural and social barriers of language learning. Sherman (2003) believed that "one reason why [authentic material] is so important for language learning is that it is a window into culture" (p.12). However, some experts do not trust the use of authentic materials. Clark (1983) stated that the media has no effect for learning language in any condition and so using authentic versus non-authentic materials is out of question. In the same way, Kienbaum and colleagues (1986) claimed that there is no meaningful difference in language learning of children who used authentic materials compared to others who learned language with traditional materials. According to Martinez (2002) using authentic materials may be culturally biased. Nostrand (1989) stated that "authentic texts from one culture may give a false impression to a student from another unless they are presented in an authentic context which makes it clear precisely what they exemplify" (p.49). According to McNeil (1994), Kilickaya (2004) and Ur (1996), lower-level learners may feel frustration and de-motivation when confronted with an authentic text. Guariento and Morely (2001) pointed that " at lower levels, however, ...the use of authentic texts may not only prevent the learners from responding in meaningful ways but can also lead them to feel frustrated, confused, and, more importantly, de-motivated" (p. 347). Kim (2000) believed that real-life language do not provide a comprehensible input for language learners at earliest stages of learning. In sum, using authentic material in language teaching has been under discussions for many years. However, the advantages of using authentic materials overweigh the difficulties. On the other hand, it is possible to overcome the difficulties by applying proper task design. Filed (1998) stated that "instead of simplifying the language of the text, simplify the task that is demanded of the student. ...With the text above the language level of the class, one demands only shallow comprehension" (p.244). Guariento and Morley (2001) stated that such challenges can be overcome by designing tasks that need relative comprehension. Totally, it is obvious that using authentic materials into the FL/SL classroom has its own advantages. The positive effects of authentic listening materials are also mentioned above. The main advantages of using authentic listening materials are the positive effect of them on motivation (Philips \& Shettlesworth, 1978; Clarke 1989; Peacock, 1997; cited in Richards, 2001). Authentic listening materials cause exposure to real language and are more related to natural needs of the language learners. Real-life listening materials bring the chance of applying a more creative approach toward teaching.

\subsubsection{Selecting authentic materials}

Berardo (2006) stated that there are three criteria for choosing authentic texts: suitability of content, exploitability, and readability. Suitability of content refers to the fact that the material should be chose based on students 'needs and interests. Bacon and Finneman (1990) suggested that choosing authentic material should be based on considering the culturally relevance with experience of the students. In this respect, Lee (1995) stated that "a careful and wise selection of materials focused on learners is a must if we want a positive response from them" (p.325). Exploitability means usability of the texts for developing the students' competence and teaching purposes. Readability points to the structural and lexical difficulty of the text, as well as the amount of new vocabulary and grammatical forms in it. Brown and Eskenzai (2004) indicted that the main factor for selecting appropriate authentic text should be the reader's common vocabulary knowledge and the desired vocabulary knowledge which is supposed to be gained during the course and also grammar difficulty and text cohesiveness. However, Rivers (1987) stated that content is the primary factor for choosing appropriate authentic text. He states that "although length, linguistic complexity, and interest for the student all play significant roles in the selection of materials, the single most important criterion for selection is content" (p. 50) However, Rivas (1999) and Mishan (2005) believed that learners' interests and needs are the essential factors in selecting authentic texts. Little and colleagues (1989) have mentioned that the more texts are related to learners' personal concerns and interests the deeper and more rabid the processing will be. Moreover, Lee (1995) believes that the text must be in harmony with the curriculum objectives to be able to improve the language skills of the learners. In addition, the teachers should care about both the length of the text and teaching approach at the same time. Different genres such as articles, advertisements, interviews, poems, application forms, train timetables, and brochures must be chose as authentic teaching materials. 


\subsubsection{A review of the research on using authentic listening materials}

The study of Linghu and Yunayuan (2010) has shown that use of authentic materials is obviously reasonable and effective but may face the teachers and learners with some difficulties. There are some challenges due to cultural content of the difficult language, vocabulary and complex structure (Richard, 2001). Therefore students must be sufficiently equipped with cultural background, vocabulary and grammar knowledge. They also stated that using authentic materials could be challenging for the teachers, too. So, they stated that students and teachers must have necessary preparation for using authentic materials. Furthermore, although authentic listening materials are useful for advanced learners but using authentic materials should not be dismissed for lower levels. They mentioned the ways for introducing authentic listening materials for students at earlier stages. These ways have been mentioned by various scholars in the literature.

\section{Simplifying the task:}

Every teacher may solve the increased linguistic difficulty of the authentic text by simplifying the task (Anderson \& Lynch, 1988). However, it is not always the language that makes a piece of listening difficult, difficulty may be result of the related task. It is possible to use a listening passage which is well beyond the learners' level, provided that what is demanded of the learner is correspondingly simple. There is a reverse relationship between text difficulty and task difficulty (field, 2008).

\section{Grading the text}

It should be always remembered that the authentic text do not have same types, moods and genres for all the learners in terms of difficulty level. So, it is important to use different samples. Finally, following points should be considered in grading authentic materials: repeated vocabulary; Simple structure; Simpler ideas and facts; redundancy, frequently repeated ideas/facts; same form of words repeated; very context or genre of communication which predetermines participants' behavior.

\section{Staging the listening:}

It refers to simplicity and presentation of task in progression manner. Peacock (2000) carried out a study. Studying whether authentic materials increase motivation of learners is challenging and hard. He chose two beginning -level EFL classes and used authentic and non-authentic materials. Results revealed that observed motivation increased significantly when using authentic materials. However, authentic materials were less interesting than non-authentic materials for learners. Madden (2008) used a series of techniques for adapting authentic listening and proposed the method of using materials from media and its repetition in oral mood. Chavez (1998) asked 190 university-level learners of German to rate 53 situations (composed of 12 authenticity factors) based on (a.) authenticity; (b.) contribution to language learning; (c.) ease/difficulty; and (d.) resulting anxiety/enjoyment. Results indicated that learners define authentic materials as essential and enjoyable for language learning. In contrast, there was rarely a positive correlations found between authenticity and perceived difficulty. He found that learners enjoy interacting with authentic materials while at the same time need teacher's support, especially in listening situations and when reading literary texts. In sum, it was found that learners prefer grading tasks to grading texts. Norris (2011) studied authentic video and audio for developing cultural awareness in listening and found the positive aspects of combining the visual and auditory modes. He combined the task to make authentic listening materials more tuning for beginners. Finally, it was concluded that accompanying tasks provide authentic tools for beginning English Language Learners to learn to use language as it is spoken by native-speakers. He found that the videos, materials, and tasks on varied cultural themes can be used as supplementary materials.

\subsubsection{Related Review of Literature in Iran}

The numbers of studies in Iran in this flied are rare. Here are some examples: The study of the problem of authenticity and comprehensibility of linguistic input in second language acquisition' done at Tabriz University by Nowrouzi (1997). This study considered the issues of comprehensibility of linguistic input and its authenticity in SL acquisition. It is stated that if the learners are exposed to simplified comprehensible texts, the naturalness and authenticity is lost. In other words, exposing language learners to authentic texts can be challenging if not impossible. He stated the controversial issued about how to balance the use of simplified and authentic materials to motivate better learning. Furthermore, the nature of simplified and authentic materials is discussed and some solutions are provided. He recommended that presentation should be authentic life and activities should be simple. Another thesis by Keshavarz Hedayati (1999) cited in Naseh, (2007)at Tehran Azad Islamic University, Central Branch titled as "the effect of authentic broadcast materials on the listening comprehension of Iranian EFL Learners" was done to examine the priority of authentic materials over the simplified ones and their effect on language learners' motivation. Two groups of male and female participants were randomly assigned to the experimental and control group. The participants had passed the intermediate level of language learning. The experiment group received authentic broadcast, while the control group received simplified materials during the study. The experimental group also received necessary background knowledge. After 13 sessions of teaching, for both groups, one test was administered. After analyzing the data, the author concluded that using authentic materials has a meaningful effect on students' comprehension and motivation. The latest study in the realm of authentic listening materials was carried out by Mousavi \& Iravani (2012). They studied the effect of authentic materials on listening comprehension of Iranian language learners who studied at higher intermediate level. Having chosen two groups randomly, they exposed two series of listening materials to the two groups, namely authentic and non-authentic listening materials to experimental and control group, respectively. 
They found that those who had received authentic radio-tapes obtained a higher degree of listening comprehension and proficiency. It was concluded that using authentic materials in EFL context improves learners' listening comprehension, and it has positive effects on EFL learners. Finally, Khalili \& Mahsefat (2012) conducted a research titled as " the impact of authentic listening materials on listening skills of EFL learners at elementary level". A number of 60 students at elementary proficiency level and divided them two groups, experimental and control group. After running a pretest, these two groups exposed to two series of material, authentic and simplified materials for experimental and control group respectively. The analysis and comparison of results taken from two groups in posttest revealed that, using authentic listening materials positively affect the listening ability of the learners. Further, they reported positive feedback on the part of students exposed by authentic listening materials.

\subsection{Research Questions}

The present study tries to find the answer to the following questions:

1. What are the Iranian language learners' attitudes toward the effectiveness of applying authentic materials in the English language classrooms?

2. What are the Iranian language teachers' attitudes toward the effectiveness of applying authentic materials in the English language classrooms?

Following hypotheses are suggested based on the study nature and research questions.

H1: students have positive attitudes regarding using authentic listening materials. Second hypothesis: teachers have positive attitudes regarding the use of authentic materials.

\section{Methodology}

\subsection{Participants}

The present study was done at the Rodaki Higher Institute Education, Mazandran, Iran. 100 students and 30 teachers (both male and female) participated in They were randomly chose. In order to control the level of the participants, Oxford Placement Test (OPT) was used to make sure that they are unanimously at the pre-intermediate proficiency levels. It was shown that all 60 students were at pre-intermediate level. Participants studied the course of English for general purpose and aged from 18 to 30. All of them studied non-English majors. As stated earlier, per-intermediate levels. They spoke Persian and their mother language. In addition, some of them had Turkish background and culture. They were taught using the same curriculum during the English courses.

\subsection{Research Instruments}

An English placement test (Oxford Placement Test, 2007, appendix A) teachers and students feedback survey was used in the present study. The test is paper-based and is administered to define the proficiency level of the participants. The placement test was administered to determine the proficiency level of the participants. This placement test (appendix A) consisted of 50 multiple choice questions which assess students' knowledge of key grammar and vocabulary from elementary to intermediate levels. A reading text with 10 graded reading comprehension items and also an optional writing task to assess students' ability to produce the language. The time of the test was 65 minutes. This test enables teachers to have a greater understanding of what level their students. An interview is conducted to provide a deeper understanding of teachers and students attitudes about using authentic listening materials in EFL class. It was administered to 80 students and 30 teachers who had agreed in advance to participate in a follow-up interview for the purpose of the study. Before the interview they signed consent form by which they agreed to be audio-taped. Both teachers and learners were asked five questions designed to elicit qualitative data regarding their belief, and opinions about using authentic materials in language classes, the interview was conducted face to face, the first three items for both teachers and learners were the same, whereas the two were different, all of the items were about their perception to authentic listening materials. Finally, the students were let to provide feedback on the materials they were exposed to. The instructor administered a student feedback survey (adapted from Al-Musallam, 2009) to generate the students' opinions and perspectives on instructional materials, i.e. authentic listening materials (See appendix D). It asked the effectiveness of the authentic materials form the students' perspective. The questionnaire was rated based on Likert scale and the results provided information used for conclusion of the present study. The questionnaire had 35 multiple-choice items questions to elicit data on the authentic listening materials. It was adapted from Al-Musallam (2009). In order to gain better and clearer results the questionnaire was translated into Persian language (appendix E).

\subsection{Procedures}

In this section, the procedure that was followed to conduct the study is elaborated. After selecting sixty students randomly Oxford Placement Test (OPT) (2007)(appendix A)was administered to make sure that they are unanimously at which proficiency level. Due to the peculiarity of authentic listening materials, authentic listening materials were assigned for students to be familiar with. By the same token they were assigned simplified materials which the author adapted for. Then, the questionnaires were administered among learners accordingly. Besides, teacher also received an appropriate questionnaire to elicit their attitudes. After a short introduction to the project and its objectives for teachers and learners, they were asked to study the items and agree or disagree with the statements. Furthermore Teachers' and learners' perception were studied qualitatively using interviews. Although, the recorded observations may not help to understand the participants' attitudes, it will be employed in this survey as a complementary tool to obtain more understanding about the reasons and condition of using first language by EFL teachers and learners. First, define authentic materials. The participants are then asked to indicate their experience in teaching EFL. The questionnaire 
presents in the form of multiple-choice questions. Participants are allowed to choose more than one answer according to their opinions. In addition, they are allowed to add their own comments regarding any item.

\section{Result}

The results were depicted in following tables.

Table1. Student's attitudes regarding authentic listening materials

\begin{tabular}{|c|c|c|c|c|c|c|c|c|c|c|}
\hline & $\mathbf{S A}$ & $\%$ & $\mathbf{A}$ & $\%$ & D & $\%$ & SD & $\%$ & Mean & Std. D \\
\hline 1 & 13 & 36.1 & 15 & 41.7 & 3 & 8.3 & 5 & 13.9 & 2.00 & 1.014 \\
\hline 2 & 19 & 52.8 & 10 & 27.8 & 2 & 5.6 & 5 & 13.9 & 1.81 & 1.064 \\
\hline 3 & 3 & 8.3 & 7 & 19.4 & 18 & 50.0 & 8 & 22.2 & 1.86 & 0.867 \\
\hline 4 & 14 & 38.9 & 6 & 16.7 & 12 & 33.3 & 4 & 11.1 & 2.17 & 1.082 \\
\hline 5 & 15 & 41.7 & 11 & 30.6 & 7 & 19.4 & 3 & 8.3 & 1.94 & 0.984 \\
\hline 6 & 1 & 8.3 & 7 & 19.4 & 5 & 13.9 & 21 & 58.3 & 3.22 & 1.045 \\
\hline 7 & 11 & 30.6 & 13 & 36.1 & 8 & 22.1 & 4 & 11.1 & 2.14 & 0.990 \\
\hline 8 & 2 & 5.6 & 2 & 5.6 & 10 & 27.8 & 22 & 61.1 & 3.44 & 0.843 \\
\hline 9 & 17 & 47.2 & 7 & 19.4 & 6 & 16.7 & 6 & 16.7 & 2.03 & 1.0158 \\
\hline 10 & 19 & 38.9 & 17 & 27.8 & 6 & 16.7 & 6 & 16.7 & 2.11 & 1.116 \\
\hline 11 & 16 & 44.4 & 12 & 33.3 & 2 & 5.6 & 6 & 16.7 & 1.94 & 1.094 \\
\hline 12 & 9 & 25 & 12 & 33.3 & 12 & 33.3 & 3 & 8.3 & 2.25 & 0.937 \\
\hline 13 & 10 & 27.8 & 10 & 27.8 & 13 & 36.1 & 3 & 8.3 & 2.25 & 0.967 \\
\hline 14 & 9 & 25 & 7 & 19.4 & 12 & 33.3 & 14 & 38.9 & 2.69 & 1.231 \\
\hline 15 & 7 & 19.4 & 2 & 5.6 & 14 & 38.9 & 13 & 36.1 & 2.92 & 1.105 \\
\hline 16 & 3 & 8.3 & 2 & 5.6 & 12 & 33.3 & 19 & 52.8 & 3.31 & 0.920 \\
\hline 17 & 12 & 33.3 & 15 & 41.7 & 7 & 19.7 & 2 & 5.6 & 1.97 & 0.878 \\
\hline 18 & 13 & 36.1 & 18 & 50.0 & 4 & 11.1 & 2 & 5.6 & 1.92 & 0.906 \\
\hline 19 & 20 & 55.6 & 9 & 25 & 6 & 16.7 & 1 & 2.8 & 1.67 & 0.863 \\
\hline 20 & 1 & 2.8 & 5 & 13.9 & 11 & 3.6 & 19 & 38.9 & 33.3 & 0.828 \\
\hline
\end{tabular}

The survey contained 35 multiple-choice items (appendix D). The mean for each item has been shown in the table. Items $(1,8,9,10,11,12,13,14,15,16,17,18,19)$ on the participants' attitudes toward authentic listening materials and their preferences reflected the high value for mean ( mean $=3.5, \mathrm{p}=65 \%)$. Conversely, items $(2,3,4,5,6,7$, and 20) asking the participants about the lack of authentic listening materials showed lower mean score (mean $=2.10$ and $p=30 \%$ ). By the same token item (20) on participants' motivation also showed high mean and high percentage $(\mathrm{mean}=3.24 \mathrm{p}=60 \%)$. The sources most preferred by participants are movie and music (mean $=3.24 \mathrm{p}=65 \%$ and mean $=3.1 \mathrm{p}=63 \%$ ). Finally the materials most preferred by the participants are film and TV (mean=3.5 $\mathrm{p}=67 \%$ ). The findings of the survey showed that the experimental group responded favorably on the majority of the items and showed a higher level of satisfaction with the authentic listening materials. The mean and standard deviation percentages indicated that the experimental group scored higher in most of the variables, such as willingness and preference to use authentic materials, tendency towards listening to authentic listening materials, usability of authentic listening materials in society and out of class situation, motivational power of authentic listening materials, the effect of authentic listening materials on speaking, grammar, vocabulary proficiency and the effectiveness of authentic listening materials on listening skills. In addition, the most significant sources of authentic listening materials were movie and music. In addition, TV and movie were the most accessible sources for the students. The results of this survey confirmed that Iranian EFL learners at preintermediate proficiency level hade positive attitudes toward authentic listening materials.

Table 2. Teacher's attitudes toward the type of listening materials

\begin{tabular}{|c|c|c|c|c|c|c|c|c|}
\hline \multirow{2}{*}{$\begin{array}{l}\text { Types of } \\
\text { materials/ }\end{array}$} & \multicolumn{2}{|l|}{ Authentic } & \multicolumn{2}{|l|}{ simplified } & \multicolumn{2}{|l|}{ Both } & \multirow[t]{2}{*}{ Mean } & \multirow[t]{2}{*}{ S.d } \\
\hline & Frequency & $\%$ & Frequency & $\%$ & Frequency & $\%$ & & \\
\hline Q2 & 3 & 10 & 3 & 10 & 24 & 80 & 2.70 & .651 \\
\hline Q3 & 3 & 10.0 & 18 & 60.0 & 9 & 30.0 & 2.20 & .610 \\
\hline
\end{tabular}

Types of Authentic simplified Both Mean S.d materials/ Q2 3 Frequency \% 10 Frequency \% 310 Frequency \% 2480 2.70 651 Q3 310.01860 .0930 .02 .20 .610 . This table illustrates teachers' ideas regarding the type of materials for listening classes namely, authentic, simplified or both. As it is obvious, majority of the teachers (about $80 \%$ ) believed that a listening class with both authentic and simplified materials would be the best one. 
Table 3. Teachers' attitudes toward the importance of listening

\begin{tabular}{|c|c|c|c|c|c|c|c|c|c|c|c|c|}
\hline $\mathbf{Q}_{\mathbf{n}}$ & $\overline{\mathbf{S A}}$ & & $\mathbf{A}$ & & $\mathbf{N}$ & & D & & SD & & Mean & S.d \\
\hline Item & Freq. & $\%$ & Freq. & $\%$ & Freq. & $\%$ & Freq. & $\%$ & Freq. & $\%$ & & \\
\hline Q4 & 8 & 26.7 & 6 & 20 & 6 & 20 & 6 & 20 & 4 & 13.3 & 2.73 & 1.413 \\
\hline Q5 & 16 & 53.3 & 5 & 16.7 & 4 & 13.3 & 3 & 10.0 & 2 & 6.7 & 2.00 & 1.313 \\
\hline Q6 & 5 & 16.7 & 7 & 23.3 & 7 & 23.3 & 6 & 20.0 & 5 & 16.7 & 2.97 & 1.351 \\
\hline Q7 & 9 & 30.0 & 7 & 23.3 & 5 & 16.7 & 5 & 16.7 & 4 & 13.3 & 2.60 & 1.429 \\
\hline
\end{tabular}

Table 4. Teachers' attitudes regarding authentic listening materials

\begin{tabular}{|c|c|c|c|c|c|c|c|c|c|c|c|c|}
\hline$\overline{\text { Qn }}$ & SA & & $\mathbf{A}$ & & $\mathbf{N}$ & & D & & SD & & Mean & S.d \\
\hline Item & Freq. & $\%$ & Freq. & $\%$ & Freq. & $\%$ & Freq. & $\%$ & Freq. & $\%$ & & \\
\hline Q8 & 6 & 20.0 & 7 & 23.3 & 6 & 20.0 & 6 & 20.0 & 5 & 16.7 & 2.90 & 1.398 \\
\hline Q9 & 6 & 20.0 & 6 & 20.0 & 7 & 23.3 & 6 & 20.0 & 5 & 16.7 & 2.93 & 1.388 \\
\hline Q10 & 8 & 26.7 & 7 & 23.3 & 5 & 16.7 & 5 & 16.7 & 5 & 16.7 & 2.10 & .845 \\
\hline Q11 & 8 & 26.7 & 6 & 20.0 & 6 & 20.0 & 4 & 13.3 & 6 & 20.0 & 2.80 & 1.495 \\
\hline Q12 & 6 & 20.0 & 7 & 23.3 & 6 & 20.0 & 6 & 20.0 & 5 & 16.7 & 2.90 & 1.398 \\
\hline Q13 & 6 & 20.0 & 9 & 30.0 & 6 & 20.0 & 4 & 13.3 & 5 & 16.7 & 2.77 & 1.382 \\
\hline Q14 & 5 & 16.7 & 8 & 26.7 & 7 & 23.3 & 6 & 20.0 & 4 & 13.3 & 2.87 & 1.306 \\
\hline Q15 & 5 & 16.7 & 8 & 26.7 & 9 & 30.0 & 4 & 13.3 & 4 & 13.3 & 2.80 & 1.270 \\
\hline Q16 & 8 & 26.7 & 9 & 30.0 & 7 & 23.3 & 3 & 10.0 & 3 & 10.0 & 2.47 & 1.279 \\
\hline Q17 & 8 & 26.7 & 7 & 23.3 & 6 & 20.0 & 4 & 13.3 & 5 & 16.7 & 2.70 & 1.442 \\
\hline Q18 & 5 & 16.7 & 7 & 23.3 & 6 & 20.0 & 6 & 20.0 & 6 & 20.0 & 3.03 & 1.402 \\
\hline Q19 & 6 & 20.0 & 7 & 23.3 & 8 & 26.7 & 5 & 16.7 & 4 & 13.3 & 2.80 & 1.324 \\
\hline Q20 & 11 & 36.7 & 6 & 20.0 & 5 & 16.7 & 3 & 10.0 & 5 & 16.7 & 2.50 & 1.503 \\
\hline Q21 & 7 & 23.3 & 6 & 20.0 & 6 & 20.0 & 5 & 16.7 & 6 & 20.0 & 2.90 & 1.470 \\
\hline Q22 & 8 & 26.7 & 6 & 20.0 & 7 & 23.3 & 5 & 16.7 & 4 & 13.3 & 2.70 & 1.393 \\
\hline Q23 & 5 & 16.7 & 8 & 26.7 & 7 & 23.3 & 4 & 13.3 & 6 & 20.0 & 2.93 & 1.388 \\
\hline Q24 & 5 & 16.7 & 7 & 23.3 & 6 & 20.0 & 6 & 20.0 & 6 & 20.0 & 3.03 & 1.402 \\
\hline Q25 & 3 & 10 & 6 & 20 & 5 & 16.7 & 8 & 26.7 & 8 & 26.7 & 2.97 & .928 \\
\hline Q26 & 7 & 23.3 & 11 & 36.7 & 1 & 3.3 & 10 & 33.3 & 1 & 3.3 & 2.57 & 1.278 \\
\hline Q27 & 10 & 33.3 & 6 & 20.0 & 5 & 16.7 & 4 & 13.3 & 5 & 16.7 & 2.60 & 1.499 \\
\hline Q28 & 8 & 26.7 & 9 & 30 & 5 & 16.7 & 5 & 16.7 & 3 & 3.3 & 10 & .980 \\
\hline
\end{tabular}

This table depicts teachers' ideas toward the importance of listening in EFL. About 70\% believed that listening course enables students to listen and comprehend the materials outside the classroom. Teachers had similar ideas (60\%) about the motivation caused the listening course which they say push learners to learn out of the school or in the real life situation. They stated that listening class paves for students to listen out of class to other materials.

According to table 4 the responses by around $50 \%$ of the teachers on items showed that they believe that authentic listening materials introduce students to the real life use of language. The item illustrates that $45 \%$ of the teachers state that authentic listening materials help students to fulfill their needs. By the same token, around $55 \%$ of the participants believed that the using authentic listening materials enhances the listening comprehension ability of the learners compared to the simplified material. They maintained that compared with simplified materials, authentic materials help students develop their speaking abilities. However, they had no similar ideas regarding authentic listening materials and familiarity with using grammatical rules in authentic context (Item, 15). On the contrary, about 50\% stated that (Item, 17) authentic listening materials increase the knowledge of vocabulary item. About $56 \%$ said that authentic listening materials increase students' motivation on outside classroom listening. Teachers participated in the study said that it is difficult to get access to authentic listening materials and they unanimously argued that selecting authentic listening materials is difficult.( Items, 24, 25, 26, 27, 28).

Table 5. Teachers' attitudes on the initial exposure to authentic materials

\begin{tabular}{|c|c|c|c|c|c|c|c|c|c|c|c|c|}
\hline $\mathbf{Q}_{\mathbf{n}}$ & SA & & $\mathbf{A}$ & & $\mathbf{N}$ & & D & & SD & & Mean & S.d \\
\hline item & Freq. & $\%$ & Freq. & $\%$ & Freq. & $\%$ & Freq. & $\%$ & Freq. & $\%$ & & \\
\hline Q29 & 8 & 26.7 & 8 & 26.7 & 6 & 20 & 4 & 13.3 & 4 & 13.3 & 3.73 & 1.613 \\
\hline Q30 & 16 & 53.3 & 5 & 16.7 & 3 & 10 & 4 & 13.3 .0 & 2 & 6.7 & 3.78 & 1.313 \\
\hline Q31 & 5 & 16.7 & 7 & 23.3 & 7 & 23.3 & 6 & 20.0 & 5 & 16.7 & 2.97 & 1.351 \\
\hline
\end{tabular}

Table number 4.7 extracts teachers' ideas regarding the initial exposure to authentic listening materials. Unlike many experts in the realm of TEFL, $60 \%$ of teachers in this study believed that learners should be exposed to these materials early (Item, 29). About 70\% of teacher (Item, 30) said that the intermediate level students should receive authentic materials. Finally, the teachers stated that advance proficiency level is late to expose authentic listening materials. 
Table 6. Teachers' attitudes regarding the kinds of authentic materials in class

\begin{tabular}{|c|c|c|c|c|c|c|c|c|c|c|c|c|}
\hline $\mathbf{Q}_{\mathbf{n} / \text { item }}$ & SA & & $\mathbf{A}$ & & $\mathbf{N}$ & & D & & SD & & Mean & S.d \\
\hline TV commercials & $\begin{array}{l}\text { Freq. } \\
6\end{array}$ & $\begin{array}{l}\% \\
20\end{array}$ & $\begin{array}{l}\text { Freq. } \\
9\end{array}$ & $\begin{array}{l}\% \\
30\end{array}$ & $\begin{array}{l}\text { Freq. } \\
6\end{array}$ & $\begin{array}{l}\% \\
\% \\
20\end{array}$ & $\begin{array}{l}\text { Freq. } \\
5\end{array}$ & $\begin{array}{l}\% \\
16.7\end{array}$ & $\begin{array}{l}\text { Freq. } \\
4\end{array}$ & $\begin{array}{l}\% \\
13.3\end{array}$ & 2.73 & 1.337 \\
\hline cartoons & 16 & 53.3 & 5 & 16.7 & 3 & 10 & 4 & 13.3 .0 & 2 & 6.7 & 2.53 & 1.432 \\
\hline News clips & 10 & 33.3 & 6 & 20 & 6 & 20 & 4 & 13.3 & 4 & 13.3 & 2.97 & 1.351 \\
\hline Soap opera & 9 & 30.0 & 7 & 23.3 & 3 & 10.0 & 11 & 36.7 & 4 & 13.3 & 2.53 & 1.279 \\
\hline $\begin{array}{l}\text { Internet } \\
\text { materials }\end{array}$ & 6 & 20 & 8 & 26.7 & 6 & 20.0 & 6 & 20.0 & 4 & 13.3 & 2.80 & 1.349 \\
\hline $\begin{array}{l}\text { Taped short } \\
\text { stories and novel }\end{array}$ & 17 & 56.7 & 3 & 10.0 & 4 & 13.3 & 3 & 10.0 & 3 & 10.0 & 2.07 & 1.437 \\
\hline Radio & 5 & 16.7 & 13 & 43.3 & 9 & 30.0 & 1 & 3.3 & 2 & 6.7 & 2.40 & 1.037 \\
\hline Song & 11 & 36.7 & 8 & 26.7 & 6 & 20 & 2 & 6.7 & 3 & 10 & 1.97 & .928 \\
\hline
\end{tabular}

Regarding the type of authentic listening materials, Taped short stories and novel, cartoons, TV and Songs received highest selections by teachers. $75 \%$ of teachers in this study said that they prefer Taped short stories and novel, around $65 \%$ of them stated that they select cartoons, TV. The least was Radio, only $45 \%$ of teacher said they select it.

Table 7. Teachers' attitudes regarding factors in selecting authentic materials in class

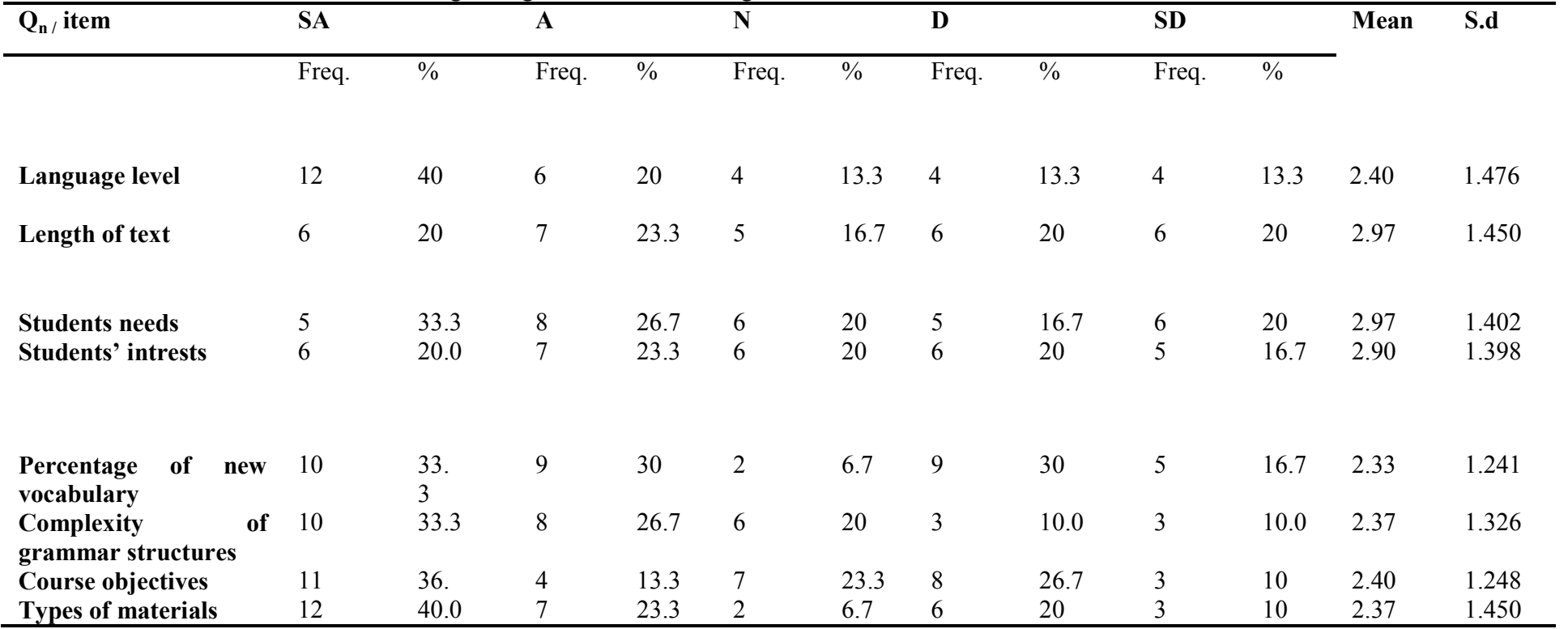

Teachers participated in this study had similar idea regarding the factors based on which they select their authentic listening materials. $60 \%$ of them stated that they select authentic listening materials according to the language level, $53.3 \%$ said the criteria they use for the selection of authentic listening materials is the Length of text. Similarly, 53.3\% stated that Students needs is their light in material selection. $66.3 \%$ believed that Percentage of new vocabulary is important to them in the selection of authentic listening materials. $60 \%$ teachers participating in this study believed that, complexity of grammar and structures is their favorite criterion in their selection. Finally, course objectives and types of materials showed 49.3 and 63.3 percent respectively, by teachers as criteria of selecting authentic materials.

\section{Discussion}

In the present research, a placement test was administered to the participants to have harmonious groups and based on the results; all students were at the same level. Similarly, they were divided to two groups to receive two series of materials, authentic materials and simplified materials. The results suggested that Iranian EFL learners at preintermediate proficiency level show significantly positive attitudes toward using authentic listening materials (Bacon and Finnemann, 1990). In fact the result is not surprising as the students moved from their limited learning environment (using only textbooks) to another environment connecting them with the language as it is used in the real world by native speakers. The use of authentic materials also seemed to create a lot of interest among the students; they appeared to enjoy learning by being able to deal with a variety of authentic texts away from those of their usual classes (simplified). The students' positive attitudes were based on the advantages of authentic materials brought into FL instruction. The students agreed that authentic materials; increased their knowledge of vocabulary for real situations, introduced how to use language in the real world, improved their cultural understanding, language proficiency and listening comprehension, were interesting, fulfilled their needs, and enabled them to improve their 
writing. These findings are consistent with the current studied which provided evidence supporting the advantages of using authentic materials in language learning classes. In addition, the results of the current study have shown that the majority of the student participants indicated that authentic materials increased their motivation. The researches done before also found that motivation is the key element for using authentic materials in language classes. The majority of students participating in the present study did not believe in difficulty of authentic materials to be understood. The analysis of the results showed that the teacher participants have a positive attitude toward the use of authentic materials in their listening classes. As stated earlier, a growing body of researchers believes that authentic materials helps the students to know how to use language in real condition and improves the overall proficiency of the students at four main skills of language learning. Regarding the criteria they would apply in their selection of authentic materials, the teachers indicated that language level was the first, the students' interests the second and their needs the third. Moreover, the teachers ranked the percentage of new vocabulary fourth and course objectives fifth in deciding upon texts to use. The length of the text, complexity of grammatical structures, and type of text all were ranked. In sum, findings of the present study showed that students at pre- intermediate level have a positive attitude toward authentic listening materials. The present study also indicated that exposure to authentic materials in the classroom will improve the comprehension of the EFL learners. It can be concluded that in order to prepare the students and language learners to interact in real life condition it is better to use authentic listening materials. It was also showed that participants in experimental group had positive attitude toward authentic listening materials. Finally, authentic listening materials are found to be more effective than simplified listening materials at elementary level, provided that they are instructed in the logical manner as it was reiterated in the literature (Anderson \& Lynch, 1988; Field, 2008; Lingzhu \&Yuanyuan, 2010). As they pointed out, limiting listeners to graded materials, appropriate to their levels, leads to their disqualification from the outside face to face wrestling with the language. As they indicated, task simplification, text gradation and staging the listening progression should be taken into account while introducing authentic (listening) materials to pre- intermediate students. By the same token, it can be understood teachers also have a positive attitudes toward authentic material for students at pre-intermediate level.

\section{Suggestion}

The present study emphasizes the need for further study about the effect of authentic listening materials in developing listening skills. Due to favorable impact of authentic listening materials, there is a need to study the effectiveness of different genres of authentic listening materials. Next, a more comprehensible study can be done to include all the possible modes and sources of authentic materials from different sources to have more pedagogical significance. It is also possible to compare and contrast the efficiency of the authentic materials in developing listening skills of the learners in terms of stress patterns, vocabulary and other components of listening materials. Finally, the attitudes of teachers and learners at other levels of proficiency will be valuable to study.

\section{References}

Adams, T. (1995). What makes materials authentic? (ERIC Document Reproduction Service No. ED 391389).

Allen, J., \& Widdowson, H. G. (1979). Teachingthe communicative use of English. In C. Brumfit \& K. Johnson (Eds.), The communicative approach to language teaching (pp. 124-142). Oxford: Oxford University Press.

Al-Musallam, E .I. (2009).College instructors' and learners' attitudes to authentic EFL reading materials in Saudi Arabia. Unpublished thesis.

Allwright, R. (1981).Language learning through communication practice. In C.J. Brumfitand \&K.Johnson(eds.), The communicative approach to language teaching(pp.167-175). Oxford: Oxford University Press.

Anderson, J. R. (1985). Cognitive psychology and its implications ( $2^{\text {nd }}$ ed.). NewYork: W. H. Freeman.

Anderson, A., \& Lynch, T. (1988). Listening. New York: Oxford University Press.

Bacon, S. M. (1989). Listening for real in the foreign-language classroom. Foreign Language Annals .22(2) 543-551.

Bacon, S. M. (1992). Phases of listening to authentic input in Spanish: A descriptive study. Foreign Language Annals, 25(6), 317-334

Bacon, S.M., \& Finneman, M.D. (1990). A study of the attitudes, motives, and strategies of university foreign language students and their disposition to authentic oral and written input. The Modern Language Journal, 74(4), 459-473.

Badger, R., \& White, G. (2000). The real thing: authenticity and academic listening.English for Specific Purposes, 19, 253-267.

Baird, K., \& Redmond, M, (Eds.) (2004). The use of authentic materials in the K-12 French program.Winston-Salem, NC: Wake Forest University, Department of Education.

Berardo, S. (2006). The use of authentic materials in the teaching of reading.The Reading Matrix, 6 (2), 60-69.

Berne, J .E. (1998). Examining the relationship between L2 Listening pedagogical theory and Practice. New York: W. H. Freeman.

Berne, J. E. (2004). Listening comprehension strategies: A review of the literature. Foreign Language Annals, 37(4), 521-533

Blaz, D. (2002). Bringingthe standards for foreign language learning to life. New York: Eye on Education. 
Brantmeier, C. (2008). Meeting the demands: the circularity of remodeling collegiate foreign language programs. The Modern Language Journal, 92(2), 306-309.

Breen, M.P. (1985).Authenticity in the language classroom.Applied Linguistics, 6(1), 60-70.

Brown, H. D. (2000).Principles of language learning and teaching ( $4^{\text {th }}$ ed.). New York: Addison Wesley Longman, Inc. Brown, H. D. (2000). Principles of language learning and teaching $\left(5^{\text {th }}\right.$ ed.).New York Pearson education.

Brown, J, \& Eskenazi, M. (2004).Retrieval of authentic documents for reader-specific lexical practice. In Proceedings of InSTIL/ICALL Symposium, Venice, Italy.

Brown,J, \& Rodgers, T. (2002). Doing second language research. Oxford: Oxford University Press.

Brown, G., \& Yule, G. (1983). Teaching the spoken language: an approach based on the analysis of spoken English. New York:Cambridge University Press.

Brusch, W. (1991). The role of reading in foreign language acquisition: Designing an experimental project. ELT Journal, 45(2), 156-163.

Butt, M., Sharif, M. M., Naseer-ud-Din, M., Hussain , I., Khan, F., \& Ayesha, U. (2010). Listening comprehension problems among the students: A case study of three govt. boys' higher secondary schools. European Journal of Social Sciences, 18(2), 311-315.

Call, M. E. (1985). Auditory short term memory, listening Comprehension \& input Hypothesis. TESOL Quarterly, 19, 765-781.

Carney, C., \& Franciulli, M. (1992). The use of authentic reading materials in the business language classroom. (ERIC Document Reproduction Service No. ED 373538)

Chavez, M. (1998). Learner's perspectives on authenticity.IRAL, 36(4), 277-306.

Clarke, D. F. (1989). Materials adaptation: why leave it all to the teacher? ELT Journal, 43(2),133-41.

Clarke, D. (1990).Communicative theory and its influence on materials production. Language Teaching, 25(1), 73-86.

Crossely, A. S, McCarthy, P. M, Louwerse, M. M, \& McNamara, D. S. (2007). A linguistic analysis of simplified and authentic text. Modern Language Journal,91(4),15-30.

Darian, S. (2001). Adapting authentic materials for language teaching. English Teaching Forum, 39(2), 27-40.

De Beaugrande, R. A., \& Dressler, W. (1981). Introduction to text linguistics. London: Longman.

Deerwester, S., Dumais, S. T., Furnas, G. W., Landauer, T. K., \&Harshman, R. (1990). Indexing by latent semantic analysis. Journal of the American Society for Information Science, 41, 391407.

Devitt, S. (1997). Interacting with authentic texts.Modern Language Journal, 81, 457-469.

Dudley-Evans, A., \& M. J. St. Jones. (2005). Developments in English for Specific Purposes. Cambridge: Cambridge University Press.

Dunkel, P. A., \& Davis, J. N. (1994). The effects of rhetorical signaling cues on the recall of English lectureinformation by speakers of English as a native or second language. In J. Flowerdew (Ed.), Academic listening:Research perspectives. pp. 55-74

Elbaum, S. (2001). Grammar in context one. Boston: Heinle \& Heinle.

Ellis, R. (1993). Naturally simplified input, comprehension and second language acquisition. Oxford: Oxford University Press.

Ellis, R. (1994). The study of second language acquisition.Oxford: Oxford University Press.

Farhady,H. Ja'farpur, A. Birjandi, P. (1994). Testing language skills: From theory to practice. Tehran. SAMT publication.

Field, J. (2008). Listening in the language classroom. Cambridge: Cambridge University Press.

Flowerdew,J., \& Miller ,L. (2005).Second language listening: Theory and practice.New York: Cambridge University Press.

Ghadessy, M. (1985). Comments on recent articles on schema theory, a reader reacts: word knowledge and world knowledge. TESOL Quarterly, 192(2) 375-382. http://dx.doi.org/10.2307/3586838

Genhard, J.G. (1996). Teaching English as a foreign language: A teacher self-development and methodology. Ann Arbor: The University of Michigan Press.

Gilmore, A. (2004). A comparison of textbook and authentic interactions. ELT Journal, 58(4), 363-374.

Gonzalez, O. G. (1990). Teaching languages and Culture with authentic materials. Unpublished Ph.D. dissertation, West Virginia University, Morgantown, Virginia.

Gordon, R. D. (1985). Empathy: The state of the art and science. Paper presented at the International Conference of the World Communication Association (ERIC Document Reproduction Service No. ED 260470)

Guariento, W., \& Morley, J. (2001). Text and task authenticity in the EFL classroom.E Journal, 55(4), 347-353 
Hadley, A. (2001). Teaching language in context (3rd ed.).Boston: Thomson Heinle.

Harmer, J. (2007).The practice of English language teaching ( ${ }^{\text {th }}$ ed.).Harlow, UK: Pearson Education.

Hatch, E. \& Farhady, H. (1981). Research design and statistics for applied linguistics. Rowley, Mas.: Newbury House. Hedge, T. (2000). Teaching and learning in the language classroom. Oxford: Oxford University Press.

Herron, C., \& Seay, I. (1991). The effect of authentic oral texts on student listening comprehension in the foreign language classroom. Foreign Language Annals, 24(6), 487-495.

Hirsch, R. (1986). Define listening: synthesis and discussion (ERIC Document Reproduction Service No. ED 267 475) Honeyfield, J. (1977). Simplification.TESOL Quarterly,11, 431-440.

Howatt, A. \&J. Dakin. (1974). Language laboratory materials, ed. J. P. B. Allen, S. P. B.

Allen, \& S. P. Corder.Jacobson, E., Degener, S., \& Purcell-Gates, V. (2003). Creating Authentic Materials and Activities for the Adult Literacy Classroom: A handbook for Practitioners(pp. 123-145).NCSALL.

Jacobson, E., Degener, S., \& Purcell-Gates, V. (2003). Creating authentic materials and activities for the adult literacy classroom: A handbook for practitioners. NCSALL. Boston. World education

Johnson, M. J. (2004). A philosophy of language acquisition. New Haven: Yale University Press.

Jordan, R. R. (1997). English for academic purposes: A guide and resource for teachers. Cambridge. Cambridge University Press.

Jurafsky, D., \& Martin, J. H. (2000). Speech and language processing: An introduction to natural language processing, computational linguistics, and speech recognition. Upper Saddle River, NJ: Prentice Hall.

Kaplan, R.B. (2002) TheOxford handbook of applied linguistics. Oxford: Oxford University Press.

Keiko, K. M. (1992). Affective variables and a less commonly taught language: A study in beginning Japanese classes. Language Learning 42(3), 377-398.

Khalili, S., M. \& Mahsefat,H. (2012). The Impact of Authentic Listening Materials on Elementary EFL Learners' Listening Skills. International Journal of Applied Linguistics \& English Literature.

Kilickaya, F. (2004). Authentic materials and cultural content in EFL classrooms. The Internet TESL Journal, 10(7). Retrieved November 1, 2006 from http://iteslj.org/Techniques/Kilickaya-AutenticMaterial.html

Kienbaum, B., Russell, A., \& Welty,S.(1986).Communicative competence in foreign language learning with authentic materials. Final ProjectReport. Purdue University, Calumet, Indiana. (ERIC

DocumentReproduction Service No. ED 275200)

Kim, D. (2000). A qualitative approach to the authenticity in the foreign language classroom: A study of university students learning English in Korea. Texas Papers in Foreign Language Education, 5 (1), 189-205.

Krashen, S. (1985). The input hypothesis: Issues and implications. London: Longman.

Krashen, S.D. (1987).Principles and practice in second language acquisition.UK. Prentice Hall International.

Kumaravadivelu ,B. (2006).Understanding language teaching, from method to post method. New Jersey:Lawrence Erlbaum Associates.

Lantolf, J. P. (2000). Sociocultural theory and second language learning. Oxford:Oxford University Press.

Larsen-Freeman, D. \& Long, M. (1991). An introduction to second language acquisition research. England: Longman Lee, W.Y. (1995). Authenticity revisited: text authenticity and learner authenticity. ELT Journal, 49(4), 323-328.

Lingzhu, J.,\& Yuanyuan, Z. (2010). The use of authentic materials in teaching EFL listening. Humanizing language teaching, 12(4), 23-29.

Lund, R. J. (1990). A taxonomy for teaching second language listening. Foreign Language Annals, 23(5), $105-115$.

Lund, S. (1992). Giving your courses a dose of reality. ELT Forum, 3(1), 10-15.

Madden. J. P. (2008).Helping ESL students adapt to authentic listening Situation. St. Cloud, MN: St. Cloud State University.

Martin, R.(1987). Oral communication. English language arts concept. Portland, Oregon: State Department of Education.(ERIC DocumentReproduction Service No. ED 284314)

Martinez, A. (2002). Authentic materials: An overview. Karen's linguistic Issues.

Retrieved October 25, 2006 from http://www3.telus.net/linguisticsissues/authenticmaterials.html

Masgoret, A., \& Gardner, R. (2003). Attitudes, motivation, and secondlanguage learning: A meta-analysis of studies conducted by Gardner andassociates. Language Learning, 53(1),123-163.

Mason, A. (1994). By dint of: Student and lecturer perceptions of lecture comprehension strategies in first-termgraduate study. In J. Flowerdew (Ed.), Academic listening: Research perspectives pp. 199-218). Cambridge University Press.

Matsuta, K. (2004.). Applications for using authentic materials in the second language classroom. Retrieved June 5, 2004 from http://www.asia-u.ac.jp/English/cele/articles/MatsutaAuthentic_Mat.htm 
Maxim, H. (2002). A study into the feasibility and effects of reading extended authentic discourse in the beginning German language classroom. The Modern Language Journal,86(1),20-35.

McNeill, A. (1994, April). What makes authentic materials different? The case of English language materials for educational television. Papers presented at the Annual International Language in Education Conference, Hong Kong.

McGinnis, S., \& Ke, C. (1992). Using authentic cultural materials to teach reading in Chinese.Foreign Language Annals, 25(3), 233-238.

Miller, L. (2003). Developing listening skills with authentic materials. ESL Magazine, 6(12), 16-18.

Miller, M. (2005). Improving aural comprehension skills in EFL, using authentic materials: an experiment with university students in Nigata, Japan. Unpublished master's thesis, University of Surrey, Australia.

Mishan, M. (2004). Designing authenticity into language learning materials. Bristol: Intellect Books.

Mishan, F. (2005). Designing authenticity into language learning materials. Bristol: Intelect Ltd.

Morley, J. (1991). Listening comprehension in foreign language Instruction. Boston, USA.

Morley, J. (2001). Aural comprehension instruction: Principles and practices. In Celce- Murcia, M. (Eds.)

Teaching English as a second language (pp. 69-85). Boston: Heinle \& Heinle.

Morton, R. (1999). Abstracts as authentic material for EAP classes. ELT Journal, 53(3), 177-182.

Mousavi, S., A. \& Iravani, H. (2012). The effect of authentic versus non-authentic aural materials on EFL learners ' listening comprehension. English language and literature studies 2(1) 21-27

Naseh, M., A.(2007). Thesis and dissertation abstracts in TEFL and related disciplines in

Iranian universities and research institutes. Tehran. Allame Tabatabaie university publications.

Nation .I.S.P, J. Newton (2009). Teaching ESL/EFL Listening and Speaking. New York. Routledge

Navarro, D. (2014). Framing the picture: A preliminary investigation into experts' beliefs about the roles and purposes of self-access centres. Studies in Self-Access Learning Journal, 5(1), (8-28).

Norris, N. N. (2011).Using authentic videos to enhance language and cultural instruction in formal English language learning setting :Ten videos and accompanying lessons, UMI 1496825. ProQuestLLC.

Nostrand, H. (1989). Authentic texts and cultural authenticity: An editorial. The Modern Language Journal, 73(1),4952.

Nunan, D. (1989). Designing tasks for the communicative classroom. Cambridge: Cambridge University Press.

Nunan, D. (1999). Second language teaching and learning. UK: Heinle \& Heinle publishers

Otte, J. (2006). Real language to real people: a descriptive and exploratory case study of the outcomes of aural authentic texts on the listening comprehension of adult ESL students enrolled in an advanced ESL listening course. Dissertation Abstracts International, 218B. (UMI No. 3212979)

Oxford, R. (1993). Research update on L2 listening. System, 21,205-11.

Peacock, M. (1997). The effect of authentic materials on the motivation of EFL learners.ELT Journal, 51(2), 144-156.

Pearson, P. D. (1983). Instructional implications of listening comprehension research.Urbana: University of Illinois, Center for the Study of Reading.

Peterson, E. (2010). Internet-based resources for developing listening. Studies in Self-Access Learning Journal, 1 (2). $139-154$.

Richards, J, C.(2001).Curriculum development in language teaching. Cambridge: Cambridge University Press.

Richards, J. C.(2005). Tactics for listening. Oxford: OxfordUniversity Press.

Richards, J.(1983), Listening comprehension: approach, design, procedure. TESOL Quarterly, 17(2), 219-239.

Richards, J. C., \&Renandya, W. A. (2002). Methodology in language teaching. Cambridge Cambridge University Press.

Ring, L. (1986). Authentic language and authentic conversational texts. Foreign Language Annals, 19(3), $203-208$.

Rivers, W. (1966). Listening comprehension. Modern Language Journal, 50, 196-204.

Rivers, W. M. (1981). Teaching foreign language skills (2nd ed.). Chicago: University of Chicago Press.

Rogers, C. V. (1988). Language with a purpose: using authentic materials in the foreign language classroom. Foreign Language Annals, 21(5), 467-476.

Ronald, K, \& Roskelly, H. (1985). Listening as an act of composing. Paper presented at the 36th Conference on College Composition and Communication. (ERIC DocumentReproduction Service No. ED 257094)

Rost, M. (2002).Teaching and researching listening. London, UK: Longman.

Saito, Y. (1994). The MBA and Japanese: Teaching practical language skills in authentic contexts. Theory into Practice, 33(1), 34-40. 
Sanderson, P. (1999), Using newspapers in the classroom. Cambridge: Cambridge University Press.

Schmitt, N. (2002).An introduction to applied linguistics. Oxford: Oxford University Press.

Schulz, R. (1991).Second language acquisition theories and teaching practice: How do they fit? The Modern Language Journal, 75, 17-26

Shortall, T. (2001), Distinctions and dichotomies: Artificial and authentic. English Teaching Professional, 21(2), 3545.

Soanes,C., \& Stevenson, A. (2005). Oxford Dictionary of English (Revised ed.). Oxford:Oxford University Press.

Strother, D. B. (1987). Practical applications of research: on listening. Phi Delta Kappan, 68 (8),pp. 625-628.

Swan, M. (1985). A critical look at the communicative approach.ELT Journal 39(2), 76-84.

Thomlison, T. D. (1984, March). Relational listening: Theoretical and practicalconsiderations. Paper presented at the Annual Meeting of the 5th International Listening Association. (Eric Reproduction Service Number ED 257165)

Thanajaro, M.,\&Shrum, J. L.(2000).Using authentic materials to develop listening

comprehension in the English as a second language classroom. Unpublished doctoral dissertation. Virginia Polytechnic Institute and State University,Blacksburg,Virginia.

Taylor, D. (1994). Inauthentic authenticity or authentic inauthenticity?TESL-EJ, 1(2), 27-43.

Ur, P. (1984). Teaching listening comprehension. Cambridge: Cambridge University Press.

Vandergrift, L. (1999). Facilitating second language listening comprehension: Acquiring Successful Strategies.ELT Journal,53,168-76.

Vigil, V. (1987). Authentic texts in the college-level Spanish I class as the primary vehicle of instruction. Unpublished doctoral dissertation. University of Texas at Austin.

Weyers, J. R. (1999). The effect of authentic video on communicative competence. Modern Language Journal, 83(3), 339-34.

Widdowson, H. G. (1978). Explorations in applied linguistics. Oxford: Oxford University Press.

Widdowson, H.G. (1976). Theauthenticity of language data. In J. Fanselow \& R. Crymes (Eds.) On TESOL '76 (pp. 261-270). Washington, D.C.: TESOL.

Widdowson, H.G. (1996). Comment: authenticity and autonomy in ELT. ELT Journal, 50(1), 67-68.

Widdowson, H. (1990). Aspects of language teaching. Oxford: Oxford University Press.

Widdowson, H. (1998). Context, community and authentic language. TESOL Quarterly, 32 (4), 705-616.

Wills,R. (2008). An investigation of factors influencing English listening comprehension and possible measures for improvement. Australia: University of Tasmania.

Wilt, M. E.(1950).A study of teacher awareness of listening as a factor in elementary Education. Journal of Educational Research, 43 (8), 626-636.

Wipf, J. (1984). Strategies for teaching tecond language listening comprehension. Foreign Language Annals 17(2).345480 .

Wolvin, A., \& Coakley, C. (1991). A Survey of the status of listening training in some fortune 500 corporations. Boston, Communication Education, USA.

Wong, V., Kwok, P., \& Choi, N. (1995). The use of authentic materials at tertiary level.ELT Journal, 49(4), 318-32.

Wood, D. J. (1999). Aspects of video movie English teaching. Journal of ChikushiJogakuen University, 80(11), 93-104.

Young, D. J. (1993). Processing strategies of foreign language readers: Authentic andedited input. Foreign Language

Annals, 26(4) 451-468. 